\title{
Abstract
}

\section{The Mouse Neuronal Protein 15.6 Gene Family}

\author{
Yuko Watanabe, ${ }^{1,2}$ Seiji Nishiguchi, ${ }^{1}$ Makoto Watanabe, ${ }^{1}$ Kazunori Shimada, ${ }^{1,2}$ \\ RIKEN GER Group ${ }^{3}$ and GSL Members, ${ }^{4,5}$ Koji Koyama, $^{2}$ and Hiromichi Yamanishi, ${ }^{1,6}$ \\ ${ }^{1}$ Hirakata Ryoikuen, Tsudahigashi, Hirakata, Osaka 573-0122, Japan; ${ }^{2}$ Laboratory of Developmental Biology and \\ Reproduction, Institute for Advanced Medical Sciences, Hyogo College of Medicine, Mukogawa, Nishinomiya, Hyogo \\ 663-8501, Japan; ${ }^{3}$ Laboratory for Genome Exploration Research Group, RIKEN, Genomic Sciences Center (GSC), RIKEN \\ Yokohama Institute, Suehiro-cho, Tsurumi-ku, Yokohama, Kanagawa, 230-0045, Japan; ${ }^{4}$ Genome Science Laboratory, \\ RIKEN, Hirosawa, Wako, Saitama 351-0198, Japan
}

During the course of reviewing the results of automatic annotation of 1989 clusters derived from 16,078 sequences of an adult mouse testis cDNA library, we found a cluster of 24 cDNA clones showing similarity to the mouse neuronal protein 15.6 (NP15.6) gene and named it the NP15.6-like gene. This NP15.6-like gene corresponded to an intronless gene, mapped to chromosome 15, and was expressed predominantly in the testes. Interestingly, the mouse NP15.6 gene itself is a split gene consisting of three exons, mapped to chromosome $\mathrm{X}$, and was expressed at high levels in various tissues and organs. We found two more intronless NP15.6-like genes; one was mapped to chromosome 5, and the other to chromosome $\mathrm{X}$. These two intronless genes were probably processed-type pseudogenes. Our present observations support the idea that NP15.6 family proteins have a shorter half-life and span a membrane.

\footnotetext{
${ }^{5}$ Takahiro Arakawa, Hidemasa Bono, Piero Carninci, Yoshihide Hayashizaki, and Jun Kawai. ${ }^{6}$ Corresponding author.

E-MAIL hiromiti@po.iijnet.or.jp; FAX +81-72-858-9521.

Article and publication are at http://www.genome.org/cgi/doi/10.1101/gr.1460503.
} 


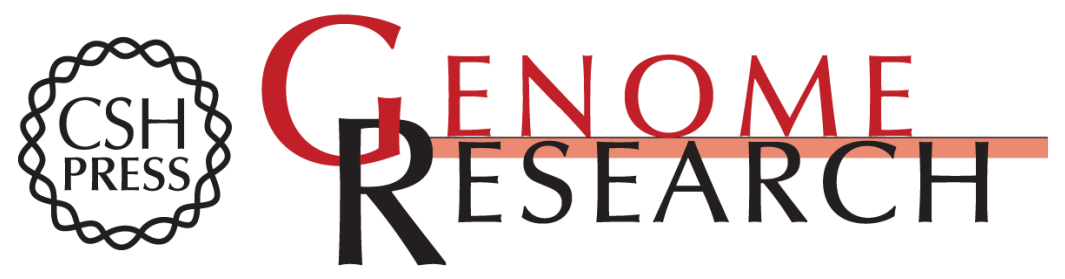

\section{The Mouse Neuronal Protein 15.6 Gene Family}

Yuko Watanabe, Seiji Nishiguchi, Makoto Watanabe, et al.

Genome Res. 2003 13: 1561

Access the most recent version at doi:10.1101/gr.1460503

\section{License}

Email Alerting Receive free email alerts when new articles cite this article - sign up in the box at the Service top right corner of the article or click here.

\section{Affordable, Accurate Sequencing.}

To subscribe to Genome Research go to: https://genome.cshlp.org/subscriptions 